\title{
Anchoring the innovation impacts of public procurement to place: the role of conversations
}

DOI:

$10.1177 / 2399654417694620$

\section{Document Version}

Accepted author manuscript

Link to publication record in Manchester Research Explorer

\section{Citation for published version (APA):}

Uyarra, E., Flanagan, K., Magro, E., \& Zabala-Iturriagagoitia, J. M. (2017). Anchoring the innovation impacts of public procurement to place: the role of conversations. Environment and Planning C: Politics and Space, 35(5), 0. https://doi.org/10.1177/2399654417694620

\section{Published in:}

Environment and Planning C: Politics and Space

\section{Citing this paper}

Please note that where the full-text provided on Manchester Research Explorer is the Author Accepted Manuscript or Proof version this may differ from the final Published version. If citing, it is advised that you check and use the publisher's definitive version.

\section{General rights}

Copyright and moral rights for the publications made accessible in the Research Explorer are retained by the authors and/or other copyright owners and it is a condition of accessing publications that users recognise and abide by the legal requirements associated with these rights.

\section{Takedown policy}

If you believe that this document breaches copyright please refer to the University of Manchester's Takedown Procedures [http://man.ac.uk/04Y6Bo] or contact uml.scholarlycommunications@manchester.ac.uk providing relevant details, so we can investigate your claim.

\section{OPEN ACCESS}




\title{
Anchoring the innovation impacts of public procurement to place: the role of conversations
}

\author{
Author accepted manuscript - accepted for publication (27/01/17) \\ in Environment and Planning C: Politics and Space \\ Elvira Uyarra $^{a^{*}}$, Kieron Flanagan $^{a}$, Edurne Magro $^{b, c}$, Jon Mikel Zabala-Iturriagagoitia ${ }^{c}$ \\ a Manchester Institute of Innovation Research, Alliance Manchester Business School, University of \\ Manchester (United Kingdom) \\ b Orkestra-Basque Institute of Competitiveness, University of Deusto, Donostia-San Sebastian (Spain) \\ c Deusto Business School, University of Deusto, Donostia-San Sebastian (Spain) \\ * Corresponding author: Elvira.Uyarra@manchester.ac.uk
}

\begin{abstract}
Public procurement is frequently touted as a means of promoting innovation at the sub-national level, but the underlying mechanisms through which this is supposed to work are seldom articulated. In particular, while the relevance of social interaction for innovation is offered as a key rationale for the use of public procurement for innovation (PPI), there is little discussion of its corresponding spatial dimensions. This paper contributes to this debate by advancing our understanding of the spatial aspects of PPI and thus of the scope for using public procurement to achieve regional innovation policy goals. We connect the PPI literature with the literatures on innovation-driven regional development around the notion of 'conversations' to capture the spatial and social aspects of interactions relevant for PPI. Different forms of spatial anchoring of procurement, presenting different challenges and opportunities for regions, are explored. We provide illustrative examples for each type, from which implications are derived for promoting place-based 'innovationfriendly' procurement.
\end{abstract}

Keywords: Public procurement, innovation, anchoring; place-based economic development.

\section{1.- Introduction}

With an estimated average contribution of around 15\% to national GDP in OECD countries (OECD, 2015), public procurement has attracted substantial attention as a potential lever to promote innovation-driven economic development and social welfare (Aho, 2006; Edler et al., 2006; Edler and Georghiou, 2007). Interest in 'public procurement for innovation' (PPI) has also been driven by growing disillusionment with the ability of traditional, supply side interventions to promote innovation and a consequent shift in interest towards the potential for so-called demand side policies that shape the conditions for the uptake of and diffusion of innovations (Edler and Georghiou, 2007). In addition, the financial crisis has brought with it significant budget pressures for traditional resource-based instruments and a renewed interest in challenge or mission-oriented policies and targeted industrial policies. 
A growing literature has laid out the rationales for using public procurement to promote innovation, assessing its impacts as well as identifying the underlying practices and barriers associated with their effective implementation (Aschhoff and Sofka, 2009; Edler and Georghiou, 2007; Georghiou et al. 2014; Edquist et al., 2015; Edquist and Zabala-Iturriagagoitia, 2012; Rolfstam, 2013; Uyarra et al., 2014). However the geographical dimension of these practices is seldom discussed. There is a limited understanding of what public procurement can achieve at multiple levels of government (Pickernell et al., 2011), and the potential role (if any) that public procurement can have in local and regional competitiveness (Lember et al., 2011). Sub-national levels typically have key budgetary and decision-making responsibility for the provision of public services, yet they are seen as lacking the scale, capabilities and resources to drive innovation through public procurement (see e.g. Lember et al., 2011; Pickernell et al., 2011; Ferreira da Cruz et al., 2013).

In this paper we will argue that there is a symbiotic relationship between innovation and place that is often overlooked in the literature on PPI. While we concur with Chicot and Bleda's (2016) argument that public procurement can be used to address a problem of coordination and growth of multiple kinds of knowledge in order to facilitate innovation and the development of markets, missing in such discussions is the role that space and distance have in shaping those knowledge interactions. We consider that innovation cannot be understood independently of space; rather it is socially constructed through conversations that are often spatially bound and shaped by place-based needs.

This paper draws from the literature on PPI and on public-private partnerships more generally and derives insights from relational views of knowledge and the 'territorial knowledge dynamics' literature (Crevoisier and Jeannerat, 2009; Rutten, 2016; Binz et al., 2014) as well as from the product development and strategy literature, particularly the work of Lester and Piore (2004) on the role of 'conversations' shaping successful innovations. We use this idea of 'conversations' as the conceptual building block of a more spatially sensitive approach to PPI and propose an analytical framework to explore the multiple geographies of such conversations, and the opportunities and trade-offs associated with 'anchoring' procurement to support place-based innovation driven advantage. Using empirical examples from the literature as illustrations, we explore the ways and contexts in which public procurement might be used to advance regional development goals.

This is important not only because the literature has thus far neglected the territorial dimensions of PPI but also given the spatial footprint and potential impact that public procurement has on local economies. Given their budgetary and decisionmaking responsibility over many public services, cities and regions can play a key role in the development of novel solutions to societal needs. It is also important at a time when place-based approaches to innovation and industrial policy are highlighting the importance of processes at the sub-national scale shaping the production and dissemination of knowledge for innovation (Barca et al., 2012; Hildreth and Bailey, 2014; Peck et al., 2013). This thinking has heavily influenced policy at the European level, most recently in the form of the 'Smart Specialisation' strategies (European 
Commission, 2012; McCann and Ortega-Argilés, 2015). The guidance documents on Smart Specialisation (European Commission, 2012) actually include public procurement as part of the recommended regional innovation instrument mix. How it is to be used, however, remains largely unarticulated. The purpose of this paper is therefore to imbue some place sensitivity into the debate of PPI, by exploring how distance and space dynamics shape the development of knowledge underpinning such innovations.

The paper is structured as follows: Section 2 provides a brief overview of the literature on PPI, highlighting a relative neglect of geography and place dynamics. Section 3 brings the social and spatial nature of innovation together around the idea of 'conversations', the geographical dimensions of which are described in section 4. Section 5 takes this discussion forward to explore the various ways procurement may be 'anchored' to place, and the tensions and challenges that may arise from them. Section 6 provides a discussion and draws some conclusions.

\section{2.- Public procurement and innovation. A missing geographical dimension}

The last decade or so has seen a renewed interest in the potential of public procurement to stimulate business innovation and accelerate the diffusion of new technologies (Edler and Georghiou, 2007; Pickernell et al., 2011). The literature has actively engaged with definitional issues and typologies around what precisely constitutes PPI, in an effort to better conceptualize and categorise PPI related interventions (e.g. Edler and Georghiou, 2007; Hommen and Rolfstam, 2009; Uyarra and Flanagan, 2010; Edquist and Zabala-Iturriagagoitia, 2012). In addition empirical studies have explored the impacts of procurement on innovation performance and identified key drivers, barriers and processes associated with its use as an innovation policy instrument (e.g. Aschhoff and Sofka, W., Edquist et al., 2000, 2015; Lember et al., 2013; Uyarra et al., 2014; Rolfstam, 2013, 2015).

Using public procurement to spur innovation has been justified on the basis of its capacity to: create new markets for products and technologies; 'pull' innovation by reducing market and technological risk for innovators; overcome 'systemic failures' by connecting users and suppliers; provide a testing ground for innovative products; and contribute to addressing societal challenges (Edler and Georghiou, 2007; Geroski, 1990; Rothwell, 1984). However discussions of the rationales associated with the use of PPI largely relate to national or sectoral policies (often large scale mission-oriented policies). Less attention has been paid to the spatial and multi-level dimensions of such rationales. Cities and small states are seen as less well placed to contribute to PPI by virtue of the limited scale of their purchasing power (Georghiou et al., 2010; Lember et al., 2011). On the other hand, smallness has also been seen as making for a more attractive testing ground for novel solutions and experimentation (Morgan and Henderson, 2002; Dale-Clough, 2015; Hodson and Marvin, 2010; Lember et al., 2015; Uyarra and Gee, 2013). Finally, knowledge asymmetries, such as those between suppliers and procurers or other end users, are key rationales for the use of procurement (Ferreira da Cruz et al., 2013). The regional innovation literature has long emphasized the role of geographical proximity as enabler of knowledge 
interactions (Boschma, 2005; Healy and Morgan, 2012). However, the PPI literature has paid little attention to the spatial dimensions of user producer interactions.

Conceptual debates have revolved around the definition of PPI and the dichotomous distinction between 'regular' and 'innovative' procurement (Edquist and ZabalaIturriagagoitia, 2012). The literature tends to associate PPI with deliberate attempts to achieve innovation (understood as the development of novel products and services). Some authors also consider procurement-related decisions that result in innovation, as a by-product of normal procurement processes. This is important particularly at the sub-national level, when innovation is less likely to be the result of a coherent or deliberate policy but rather occur as side effect of 'every day' procurement activities trying to achieve other goals (Lember et al., 2011). Acknowledging that procurement affects innovation regardless of whether public procurement is explicitly oriented towards innovation or not, Uyarra and Flanagan (2010) and Knutsson and Thomasson (2014) suggest the term 'innovation friendly' procurement, that is the use of practices and competences in general procurement that ensure that innovative solutions are not excluded or unduly disadvantaged.

Public procurement has been further categorized depending on what is being procured, for whom and how. For instance a key distinction is whether the procuring organization is the end user of the good and service (direct procurement) or whether it seeks to address the needs of others (catalytic procurement) (Edler and Georghiou 2007; Hommen and Rolfstam 2009). Uyarra and Flanagan (2010) note that procurement can vary in terms of the technical sophistication or standardisation of demand and suggest a typology based on the degree of local or user specificity of the product/service procured and the knowledge requirements for its provision. Public procurers can thus influence the degree to which demand is more dedicated or generic, or more or less standardised or specialised.

A further definitional issue has revolved around the types of innovation associated with PPI. Early approaches (e.g. Edquist et al., 2000) have been criticised for adopting an implicit focus on radical product innovations, neglecting other forms of innovation including service (Pelkonen and Valovirta, 2015), process (Yeow et al., 2015) and system innovations (Gee and Uyarra, 2013) as well as the diffusion and adoption of innovations (Uyarra and Flanagan, 2010). Edler and Yeow (2015) argue that procurement can enable solutions that do not exist (triggering demand) or which exist in the marketplace but are new for the organization (responsive demand). Rolfstam (2013: 1) defines PPI as "purchasing activities carried out by public agencies that lead to innovation", where innovation is understood broadly (i.e. as the introduction of a new good, a new method of production, the opening up of a new market, or the use of a new source of supply of raw materials or new ways of organising industries). Adopting a broad definition is vital, since most of what is actually procured by the public sector, particularly at the local level, is services. Empirical studies show that public procurement drives services innovation more than it does product innovation (Edler et al., 2011). Indeed, much procurement related innovation at the local and regional level is incremental and of a responsive nature rather than radical (Lember et al., 2011). 
Lember et al (2015: 412) note a prescriptive bias in much of the literature on PPI towards "what kind of PPI instruments and measures governments should use rather than explaining what policy and public administration institutional set-up make it possible to use these various PPI instruments and measures". Less attention, they argue, is given to the wider systemic sources of capacity. Indeed a number of studies (Edelenbos and Teisman, 2008; Edler et al., 2015; Rolfstam, 2013; Uyarra et al., 2014; Edquist et al., 2015; Edler and Yeow, 2016) have pointed to institutional, governance and capability related obstacles to the implementation of PPI. These include institutional challenges such as decentralized or 'silo' budgets, lack of a systemic view or internal coordination (between the internal end user or those responsible to deliver the service, and the procurers) and capacity and resource constraints in contracting authorities.

These impediments differ from place to place and at different levels of government (Pickernell et al., 2011). Cities and regions (or small states) often lack sufficient administrative and financial capacities to undertake PPI, and are more likely to depend on nation-state level regulation and financing, and to be exposed to rentseeking and other corrupt practices (Dale-Clough, 2015; Georghiou et al., 2010; Lember et al., 2011). Institutional contexts mediating these processes and the presence (or absence) of trust and social capital thus tend to be regionally contingent (Healy and Morgan, 2012).

Public procurement is already a multi-objective policy simultaneously pursuing economic, social and environmental goals, as well as improving transparency and cost efficiency. The additional goal of innovation adds yet another layer of complexity thus leading to potential goal conflicts and trade-offs (Edelenbos and Teisman, 2008). Policies and practices inspired by new rationales are adopted in a landscape conditioned by old ones, and are thus constrained by institutional inertia and path dependencies, which leads to differentiated uptake and orientation of such policies in different places and at different times (Dale-Clough, 2015; Laranja et al., 2008; Lember et al., 2015). Public procurement policy is therefore a mixture of different policy legacies which will in turn manifest differently at different levels of government, and as any other policy tool, it is context specific and dependent on multi-level governance arrangements (Howlett and Rayner, 2007). At the local level multiple agendas may coalesce as a result of policy layering over time, creating a potential problem of legitimacy around which policy goal to prioritise. Pickernell et al. (2011) suggest that the objectives of innovation and regional economic development in local procurement are mutually conflicting. In contrast, Lember et al. (2011) found that many Nordic-Baltic Sea cities boosted innovation when using procurement to pursue other social and environmental policy aims. Policy conflict may, according to Lowe and Feldman (2015), motivate a creative search for new solutions (and resources) that bring together multiple players and perspectives towards a common ground. Cities and regions can provide the arena where those problems and solutions are framed and where policy tensions may be negotiated and creatively resolved. Finally, they are home to so-called 'anchor organizations' (CLES, 2015b; Ehlenz, 2015; ICIC, 2011), namely local authorities, universities, further 
education colleges, hospitals, and housing organizations and other organisations who naturally have stake in a place and thus a commitment to use their resources and influence to identify and serve both anchor and community needs (Roberts and Siemiatycki, 2015).

In conclusion, several rationales justify the need for adopting a more careful spatial consideration when studying public procurement. First, a considerable share of public procurement is undertaken at subnational levels (Peck and Cabras, 2008). According to the OECD (2015), government procurement at regional and local levels accounts for, on average, $30 \%$ of all public procurement in member countries, rising to $47 \%$ in Sweden and $62 \%$ and $68 \%$ in Denmark and Canada respectively. Second, local procurement spending tends to be of a different nature and mix, often more oriented towards services (Pelkonen and Valovirta, 2015) and closer or more adapted to end user needs in relation to domains such as transport, education or personal services. This different profile is also likely to raise different questions and considerations about the nature of and potential for innovation. Third, cities and localities can become focal points for developing novel solutions, as spaces of connection between lead users and innovators that can help address challenges of both local and even eventually global relevance (Dale-Clough, 2015). Fourth, the institutional context or 'milieu' (Crevoisier and Jeannerat, 2009; Healy and Morgan, 2012) greatly impacts the ability to conduct such processes. There is thus a clear geographical stickiness to public procurement, since it both shapes and is shaped by actors that are strongly connected to a place.

\section{Innovation as conversational spaces}

In order to convey the social and spatial nature of interactions underpinning the development of innovative solutions through procurement, we adopt the notion of 'conversations', (Lester and Piore, 2004), exploring their multiple geographies (Rutten, 2016) and the opportunities for 'anchoring' them to a particular place to advance regional development goals (Lowe and Feldman, 2008). Implicit in this metaphor is the idea of knowledge creation as socially embedded within specialist communities of practice and within particular places. Adopting this approach allows us to explore the spatial dimensions of such 'conversations' in a much more nuanced way that has been the case in the literature.

The literature on territorial innovation models has highlighted the importance of geographical proximity for knowledge sharing and innovation (Moulaert and Sekia, 2003). Since much knowledge has an irreducible tacit dimension, knowledge sharing is subject to a distance decay effect, proximity maximizing the likelihood of learning and knowledge spillovers. However this has led to a polarised tacit/local and codified/global dichotomy which tends to overstate the importance of local knowledge interactions or the relevance of distant knowledge (Bathelt et al., 2004; Bunnell and Coe, 2001; Lagendijk, 2002; Oinas and Malecki, 2002) rather than reflecting "the actual workings of knowledge production and innovation" (Malecki, 2014: 378). 
Relational views of knowledge, in contrast, consider 'knowing' as involving "many geographies of organization and social interaction" (Amin and Roberts, 2008: 365). It has been argued that knowledge relies on spatial but also other proximities for its transmission, such as cognitive, organizational, social and institutional proximities (Boschma, 2005). However, according to Rutten (2016) the 'proximities' literature falls short of addressing the socio-spatial dynamics of knowledge creation, for it sees the different forms of proximity as if they were static relational states that are available separately, when in reality they are constructed simultaneously through social interaction. Knowledge happens in social spaces, aided and abetted by trust and often enabled by certain institutional settings (Amin and Thrift, 1995). The socially embedded nature of knowledge creation cannot be disconnected from the dynamics of personal networks and communities of practice (Wenger, 1998).

Rutten (2016) suggests that the notion of 'conversation' captures the socio-spatial dimension of knowledge creation better than the 'proximity' metaphor. He defines conversations as forms of knowledge creation that are intentional and on-going, as opposed to incidental and serendipitous. This intentionality is also implicit in Liedtka and Rosenblun's (1996: 148) use of 'strategic conversations' as metaphor to describe the shaping of strategic intent, for "it is through conversation that we come to cocreate the shared meaning behind the strategy". They argue that it is through such interactions that problems are framed, choices get made and the rationales underpinning them developed. Conversations are hence understood as a means for creating "collaborative advantage" (Roberts and Siemiatycki, 2015: 781), as these can promote synergies, enhance overall results and produce efficiency gains (Ferreira da Cruz et al., 2013).

In their study on new product development projects within organisations, Lester and Piore (2004) describe the development of innovations as socially defined and constructed in conversations "among people from different backgrounds and with different perspectives" (p.51). They define conversations as fluid, open-ended and interpretative forms of interaction, in contrast with more 'analytical' approaches to product development, better suited for products that "are already well defined" (p.54). As interpretative devices, they argue, conversations are often punctuated by misunderstandings or ambiguities, since even the vocabulary to describe the new product may be lacking, but it is this ambiguity that generates 'productive friction' (Stark, 2011) and is thus the key resource out of which the ideas emerge. Conversations thus allow the achievement of certain results that could not have been realized in their absence.

Thinking about conversations is similarly useful in the context of PPI, since, as Edler and Yeow (2016: 415) note, "markets for innovation are - by definition - not established, needs are often novel and [...] the business case of new solutions offered to organisations is ill-defined at best". Public procurement proceeds in stages, starting from the identification and definition of needs, their translation into functional specifications, and progressing to the tendering process, contract award and delivery. It is in the needs definition stages of the procurement process where market and user interaction is more likely to enable a novel solution (OGC 2004; 
Uyarra et al. 2014; Edler and Yeow 2016). In this 'interpretative phase' problems are shaped and needs articulated, and organizations benefit the most from external ideas. Later stages take on more analytical, problem-solving approach to awarding and delivering the contracts in the clearest, most transparent and most costeffective way possible, according to the rules and directives governing public procurement (which tend to impose strong restrictions for user-producer interaction). The successful implementation of conversations thus requires stakeholder commitment, participation, mutual interaction, joint processes of problem and solution definition, emergence of consensus, and agreement on decisions prior to and during the execution of procurement processes. This in turn calls for "reciprocity, interdependence and complementary strategic interests" between stakeholders (Roberts and Siemiatycki, 2015: 790).

Lester and Piore (2004) argue that in the early interpretative stages of innovation the role of the 'manager' is not to define clear specifications but to remove the barriers preventing conversations from taking place (e.g. between producers and consumers). They use the metaphor of hosting a cocktail party, where the host needs to choose the guests, initiate the conversation, keep it going and refresh it with new ideas. They note the importance of conversations during the process of setting up regulations, given the interconnectedness of infrastructure and product development (for instance in mobile communications, where consumer devices must work with various kinds of telephony and internet infrastructure in order to be useful), and the need to understand and anticipate how technological developments would evolve under a given regulatory regime.

Lowe and Feldman (2008) also adopt a view of the regulatory process as a shared conversational space to analyse how two different regions (Cambridge, MA, and Berkeley, CA) presented different regulatory responses to the same biosafety ordinances. Rather than considering regulation as a more or less rigid constraint for market and actor behaviour, they view it as a complex relational dynamic influenced by social and political processes, which would yield different local responses to regulatory interventions. In Cambridge, unlike in Berkeley, conversational spaces involving politicians, community activists, industry and ordinary citizens benefited emerging local industry by converting uncertainty into calculable risks, favouring standards and providing legitimacy for the emerging technology. Lowe and Feldman (2008) conclude that successfully 'anchored' conversational spaces and adaptive governance processes contributed to enhancing place-specific innovative advantage (see also Ferreira da Cruz et al., 2013).

Conversational spaces may thus be more or less anchored in a particular place. The idea of anchoring mobile knowledge and investment to place is not new but has recently captured much interest in recent economic geography debates. Markusen (1996) early on discussed how regions should make themselves more 'sticky' in 'slippery spaces' by anchoring and upgrading income-generating activities. For Crevoisier and Jeannerat (2009), knowledge develops in several stages namely generation, use circulation and anchoring. Anchoring is the other side of knowledge mobility and refers to the way in which this new knowledge interacts-or does not 
interact-with its new context (see also Vale and Carvalho, 2013). Binz et al. (2016: 182) adopt a more strategic view of anchoring as "an interactive process where regional actors mobilize knowledge, markets, legitimacy, and financial investment" to make them more locally sticky. However, the focus is normally on the supply side and anchor actors such as large firms, which remain "anchored in the regions ... [whilst] also embedded in relationships external to the region, with customers, competitors and suppliers" (Markusen, 1994: 483). Less attention has been paid to the active role that the public sector, through its purchasing decisions, may have in shaping regional economies; and generally to the demand side and creation of markets (Morgan, 2013). Whilst as already noted there is a growing recognition of the role that (public sector) anchor institutions such as universities, hospitals, and local authorities can play in contributing to place based innovation, this has hardly been incorporated into the debates around knowledge anchoring in economic geography debates.

\section{4.- Procurement as geographically anchored conversations}

The different geographical dynamics of procurement conversations can be articulated following Rutten (2016), who argues that different forms of anchoring would emerge depending on the content of conversations and how they are affected by place and distance dynamics (see also Crevoisier and Jeannerat, 2009). The geographical anchoring of procurement, and the associated trade-offs and tensions, can be similarly articulated around these dimensions. First, place dynamics reflect the extent to which the procurement is shaped by local place qualities, including the knowledge bases and expertise of firms and the knowledge community at large, as well as other characteristics of place such as culture and the demand sophistication of users. The second dimension, distance dynamics, takes account of whether the conversations informing the definition of needs and the design of the procurement process are reflective of specific economic, social and environmental needs of a location, or conversely whether they address needs and challenges that are common to other settings (bridging distance). Both dimensions are intimately intertwined and mutually reinforcing, but for the sake of clarity are here presented separately.

The combination of these dimensions leads us to the consideration of four possible scenarios (Rutten, 2016) with different challenges and trade-offs (Fig. 1). For instance multi-local anchored conversations are linked to, or relevant for, multiple places (Crevoisier and Jeannerat 2009) but are also shaped by local qualities, including research facilities and knowledge bases of local firms. The problem may not be specific to one location, but linked to a common problem shared by othersfor instance problems common to several places, such as street lighting or public transportation systems-and the solution is connected to local and global knowledge.

Single local anchored conversations benefit from local place qualities, but present weak distance dynamics. Place based assets contribute to these conversations and eventually to the development of more innovative solutions to problems. Weak distance dynamics imply that these problems and challenges may be either unique 
to a location, such as that others may be less well placed to contribute to the solution and thus less attracted to the conversation, or framed too narrowly so that their application beyond solving a one-off or specific problem may be limited. For instance the complex procurement of a navigable storm surge barrier described by Wesseling and Edquist (2016) addresses user and societal needs that are rather unique and relevant to very few places beyond the Netherlands (see also Rutten, 2016).

Geographically dispersed conversations, on the other hand, have weak place dynamics and strong distance dynamics. They are associated with a common, possibly well-known and clearly articulated and standardized, need or challenge. Individuals from many places engage in them but they are not especially shaped by nor do they shape local assets and amenities. They are not locally anchored but rather footloose. Examples could include services that are highly modular and standardized, such as IT, where local knowledge assets are disconnected or not relevant to these investments, thus investments offer little opportunities for mutual learning from the part of the supplier and the environment (Crevoisier and Jeannerat, 2009).

Finally, geographically concentrated conversations are specific to local problems and challenges not immediately relevant for or dependent on people in other places and at the same time unconnected to the local knowledge base. For instance the commissioning of certain social services or highly specified projects such as particular construction projects may involve conversations around local needs and challenges, as well as about socioeconomic and environmental objectives (e.g. Edelenbos and Teisman, 2008), but do not depend on or benefit from the quality of the knowledge base which makes those conversations footloose (Rutten, 2016).

The four scenarios above are not intended as static categories in a prescriptive typology as shown in fig. 1. Rather they are offered as a starting point from which to highlight the possible uncertainties and trade-offs associated with different policy choices, such as those between short-term efficiency gains and longer term (i.e. innovation) goals (Lember et al., 2015), or between local experimentation and large scale market creation (Uyarra and Flanagan, 2010; Morgan and Sonnino, 2013). Just as Lester and Piore (2004) show that managers may influence conversations by influencing what actors talk about and with whom, and the breath of such conversations, so public procurers can steer conversations to shape the degree to which demand is more or less anchored to place. This follows on from Uyarra and Flanagan's (2010) argument that procurement can be more dedicated or generic, or more or less standardized or specialized by for instance allowing dialogue with users and potential suppliers, broadening or restricting participation, aggregating or dividing contracts, allowing variety in technical solution and demanding new or more complex requirements, or greater quality standards.

\section{Anchoring of innovation impacts of public procurement to place: towards a framework}


What would this steering look like? In what follows we focus on three mechanisms, namely the extent to which conversations may be: contextualized or made more relevant to a place (a weak form of anchoring); anchored to place to promote mutual learning and knowledge upgrading; or consolidated to scale up and diffuse knowledge to advance place based competitiveness.

\section{1 Contextualising conversations}

Procurement may be made more relevant to place when the content of conversations informing the definition of needs and the design of the procurement process are reflective of specific economic, social and environmental needs of a location. Conversations may frame decisions "around wider considerations affecting the place" (CLES, 2015b: 15) and influence potentially footloose investment to become more attuned to the needs and challenges influencing the particular location.

In their study on school meals, Morgan and Sonnino (2007: 24) describe how the dominant food culture in Italy, and therefore the procurement of school meals, was 'legally contextualised' and "rooted in time and space". Procurement in Italian schools was based on locally anchored conversations that incorporated wider considerations related not only to health but also to the specific culture of the territory. Such on-going conversations also actively involved parents, articulated through the so called Commissione Mensa (Canteen Commissions), which in turn helped diffuse food education policy from the school canteen to the family. In the UK, by contrast, public procurement of school meals was conducted in the context of a mainstream food culture and based around generic considerations of growth, profits and efficiency, with little or no connection to regional and local spaces (see also Morgan, 2008).

As Morgan (2008) points out, there is an inherent, although often more perceived than real, tension between the ideals of social and environmental sustainability and objectives of competition, transparency and non-discrimination enshrined in European procurement directives. Indeed, while discriminatory practices such as 'buying local' are explicitly outlawed, the new European public procurement directive (2014/24/EU) allows the use of best price-quality ratio allowing integration of quality, social and/on environmental considerations in the award criteria as well as the inclusion of social considerations among the contract performance conditions.

Local authorities in England and Wales are starting to shift their practices following the passing of the Public Services (Social Value) Act in 2012 requiring public bodies to consider how the services they procure might improve the economic, social and environmental well-being of the area. This encourages local authorities to think about their social value priorities and to engage the community in defining those, as well as the way in which those priorities can be translated into tender requirements.

Examples of efforts to make procurement more relevant to place can be found in accounts of 'anchor institutions' (often from the US and Canada), leveraging their 
institutional assets to improve economic development in their area of influence, for instance through addressing problems of inequality or urban deterioration. Ehlenz (2015), CLES (2015a) and Roberts and Siemiatycki (2015) describe how universities and university hospitals in cities such as Philadelphia, Cleveland and Toronto are using their influence as purchaser and employer to boost economic opportunities through revitalisation and physical improvement strategies in the area.

Most accounts of 'anchor institutions' treat the fact that much purchasing is from sources outside of the region as a missed opportunity in terms of potential economic impact for the city or region. However they fall short of considering knowledge upgrading as additional means of anchoring. Opportunities are often depicted in an narrow and unidirectional way, focusing on the quantity rather than the quality of investment retained in the region, and neglecting how the quality of place, in terms of culture (as in the Italian food procurement example described above), knowledge assets and infrastructure can be nurtured and mobilised to co-create this investment, leading to a virtuous upgrading of local knowledge.

In other words, making procurement more relevant to place does not in itself guarantee learning, which we consider an essential feature of successful anchoring. As Crevoisier and Jeannerat (2009: 1237), "when the anchoring is strong, the learning permits an enrichment of knowledge: either of the location or of the mobile element or of both".

\section{2 Anchoring conversations}

Besides considering specific social and environmental needs of a location, procurement can also be anchored to place by means of local authorities and other purchasing authorities cultivating a greater appreciation of and better engagement with place specific assets, including specialist knowledge communities who could play a role in delivering more innovative solutions.

Public authorities often fail to appreciate existing innovations that could be incorporated into the public realm and inadvertently drive away potentially innovative suppliers who may sense a lack of competence or demand for innovation on the part of the public sector (Uyarra et al., 2014). Most of the case study cities in Lember et al. (2011) lacked procedures for a continuous market watch for the types of new solutions firms or universities could provide to address market needs.

Early conversations would enable greater awareness by public authorities of expert knowledge and increase the interest and motivation of the local knowledge base to participate in local procurement competitions (Edelenbos and Teisman, 2008). Early engagement in such conversations (via market consultation, market testing, engagement meetings and events involving not just procurers but also end users, or through more formalised means such as competitive dialogue) signal a willingness to purchase a novel solution, thus reducing the market risks perceived by suppliers (Pelkonen and Valovirta, 2015; Whyles et al., 2015), while at the same time allowing 
procurers to benefit from specialist knowledge when shaping specifications (i.e. functional and technical). Evidently, the search for relevant knowledge is not and should not be restricted to the local milieu, however a heightened awareness of existing capacity and expertise would have a strong signalling effect for local innovators.

Zabala-Iturriagagoitia (2013) describes how the City of Malmo in Sweden instigated 'creative dialogues' with experts and potential suppliers for its urban ecological development projects, leading to the regeneration of some of the most neglected areas in the city. The intention of the dialogue was that both public and private actors would benefit from sharing knowledge before the call was launched, building upon their collective expertise. Including many stakeholders in these dialogues helped to create a common understanding of the project's ambitious goals and the definitions of the requirements (mainly functional) that should be addressed by the suppliers in each call.

On-going conversations with specialist communities can also generate a trusting environment for the development of new, even unsolicited ideas and proposals (Roberts and Siemiatycki, 2015). For instance, Zelenbabic (2015) describes the development of a pilot project and eventually a full contract by the Municipality of Lolland (Denmark) around an unsolicited idea for a new cleaning system based on the use of microfibre cloths and mops of unique, thin composite fibres. Yeow et al. (2015) also describe how the idea for the development of an innovative 'closed loop' solution for confidential waste at HM Revenue and Customs (HMRC) had already been discussed with the incumbent supplier within on-going 'blue-sky' conversations over the years but a sudden crisis triggered by the loss of sensitive documents gave them the opportunity to put it into practice.

A more strategic form of anchoring would include deliberate attempts to nurture and boost local capabilities by targeting public procurement projects that are not only related to improving the public realm but also have greatest potential to nurture the local knowledge base, particularly the sectors and activities identified as strategic in the region. For instance The Galician Health Service (SERGAS) in Spain launched a series of plans focused on innovation in the hospital environment and in healthcare services which contemplated the use of new business models to exploit innovative products and services and the strengthening of synergies across the healthcare ecosystem, including mapping local innovation capacity and mobilizing expertise in healthcare management. Procurement here was used a strategic tool not only to improve health services but also to enable business innovation with export potential (Cueto and Garrido, 2013).

Such anchoring also requires extending conversations to local development actors and organizations such as chambers of commerce and cluster organisations to build up the capacity of local businesses and raise awareness of future opportunities, even aligning funding conditions for innovation support. For instance, in Galicia SERGAS early market engagement was done in sync with innovation support funding agencies. Pelkonen and Valovirta (2015) and CLES (2015b) discuss other forms of 
anchoring to improve learning that involve collaborative initiatives such as the setting up of cooperatives or the formation of supplier networks.

Locally anchored procurement need not lead to unduly privileging local and/or incumbent suppliers, which risks not only delivery of suboptimal goods or services but also risks artificially sustaining an otherwise non-competitive supply base. This is particularly the case when the knowledge and expertise required is not locally present but requires conversations with specialist but geographically dispersed suppliers and communities of practice to inform the design and eventual delivery of goods and services. However, such investments can be made more spatially sticky by linking them to local assets and thus enabling learning and local technological upgrading (Uyarra and Flanagan, 2010). This could involve sub-contracting requirements, licensing, and purchasing of complementary products and services, and other means of support directed at upgrading local suppliers (CLES, 2015). For instance, Uyarra and Gee (2014) describe the process of technological upgrading of the municipal waste management system in Greater Manchester (UK) through the engagement of global technology firms and their local anchoring by means of upskilling, subcontracting and development of proximity-based complementary activities. The innovative lighting system contract described in Edler et al. (2005) required an expertise that was not available locally, yet clear interfaces were set up between the external contractor and local service providers in order to maximise spillovers in terms of sustainability, innovation and skills upgrading.

\section{3 Bridging distance (consolidation)}

Conversations with users and the community at large, anchored around local problems and challenges, may favour the development of niche innovations. Regions and localities can become laboratories for experimentation (Morgan and Henderson, 2002) and procuring bodies lead users for a particular development which can later be diffused more widely, so that even though public procurement is responsive to local needs it can act to catalyse innovative developments on a larger scale. Some of the innovations described in Lember et al. (2011) such as the ID card example from Tallin (Estonia) were introduced to satisfy a specific social need but ultimately led to a much wider application and market diffusion.

In other cases innovations may "remain spatially isolated and politically fragile unless they are scaled up to, and validated by, the nation-state" (Morgan and Sonnino, 2013: 16). The downside of smallness is that localities may not present the possibility of economies of scale sufficient to trigger the up-scaling of such experiments. But scale is not something 'out there'; rather it is "constructed by social actors pursuing their goals within spatial frameworks" (Coenen et al., 2012: 975). Scale can thus be actively constructed by procurement decisions to bundle or aggregate demand in order to enlarge the market to facilitate the emergence of a particular technology or alter the market structure making it more attractive for new entrants (Knutsson and Thomasson, 2014; Uyarra and Gee, 2013). Generally speaking, the capacity of public administrations to act as 'lead users' would depend not only on their understanding 
of and similarities with other potential users, but also on their capacity to help align the needs of these different users in order to express a consistent demand.

Demand that is highly specific to local problems and challenges may make procurement less accessible to outsiders, thus deterring potential innovators and limiting market creation and the potential for further adoption and spillover effects. Fragmented demand may also be a disincentive for long-term investment in innovation. For instance, conversations around the 'slipper' street lighting solution in Tameside (UK) (Uyarra, 2010), while involving productive dialogue across local specialists around this novel product, did not include other local authorities from the outset and thus missed an opportunity to avoid strong resistance to adoption by neighbouring councils. Lember et al. (2011) describe how support from central government, in the form of regulation or market subsidies, were essential for the introduction of selected innovative services in the Nordic-Baltic Sea cities.

Need specificity may in fact be the result of inertia and lack of intra and interorganisational coordination stemming from silo thinking and a reluctance to share information and disseminate good practice within or across organisations (Phillips et al., 2007; Morgan, 2008; Uyarra, 2010; Edler and Yeow, 2016)-rather than truly unique or distinctive needs. For instance Yeow et al. (2015) describe the fragmented management of confidential waste disposal in HMRC prior to the adoption of the 'closed loop' solution resulting not only in poor value for money but also in limited control and traceability of (confidential) waste. Devising a better solution first required surveying and pooling data on the volume of waste generated, and on the frequency and cost of collection across the whole organisation. Similarly, consolidating data on waste disposal by each of the ten local authorities in Greater Manchester helped build a case nationally for investment in state of the art recycling and waste management technology and infrastructure (Uyarra and Gee, 2014).

Aggregation of demand-understood as the identification of common or similar current or future requirements within an organisation, and with other organisations (OGC, 2006) - can thus contribute to aligning needs and conditions and set up standards that can facilitate the provision of products and services by suppliers by providing a more visible and predictable market, and therefore appeal to a larger number of potential buyers. Wider 'conversations' leading to a consolidation of demand can also act as a lever for achieving wider local economic benefit if they lead anchor organizations such as schools, local authorities and hospitals to build common processes and a common vision to benefit the local economy, as described by CLES (2015).

Consolidating demand need not necessarily entail aggregation of supply, or may be done in such a way as to invite the market to bid for smaller bids for different elements of the requirement (OGC, 2006; Timmermans and Zabala-Iturriagagoitia, 2013), thus mitigating the potential negative effects of contract aggregation. Decisions regarding aggregation are contingent on the specific nature of the requirements and the structure of the supply market: conversations enable market- 
testing the suitability of such strategies. For instance in Greater Manchester, a decision was taken to aggregate the various waste services required into a larger, integrated contract in order to be able to achieve greater economies of scale to influence a large, vertically integrated sector into becoming more innovative (Uyarra and Gee, 2013). In other cases unbundling may be a better way to shape markets, as for instance in the food procurement project described by Knutsson and Thomasson (2014). In order to break down an oligopolistic supply market and shift a very poor standard of provision of food services, the municipality of Klippan (Sweden) chose to divide the requirements in order to attract several small providers rather than one large one. Consolidation in this case did not involve aggregation but the sharing of information. By sharing experiences with other municipalities (rather than collaborating to achieve higher volumes), others followed suit in changing practices, over time exerting change in the market (Knutsson and Thomasson, 2014).

Figure 1 below describes the different modalities of conversational spaces in procurement and the options for anchoring. Different scenarios and starting points would be relevant depending on the nature of the product or service procured, the nature of the challenge addressed and the quality and availability of specialist knowledge. Successful anchoring of knowledge involves interaction between mobile knowledge in such a way as to facilitate learning and knowledge formation processes that are not just locally relevant but also globally competitive.

Figure 1: Geographical dynamics of conversations

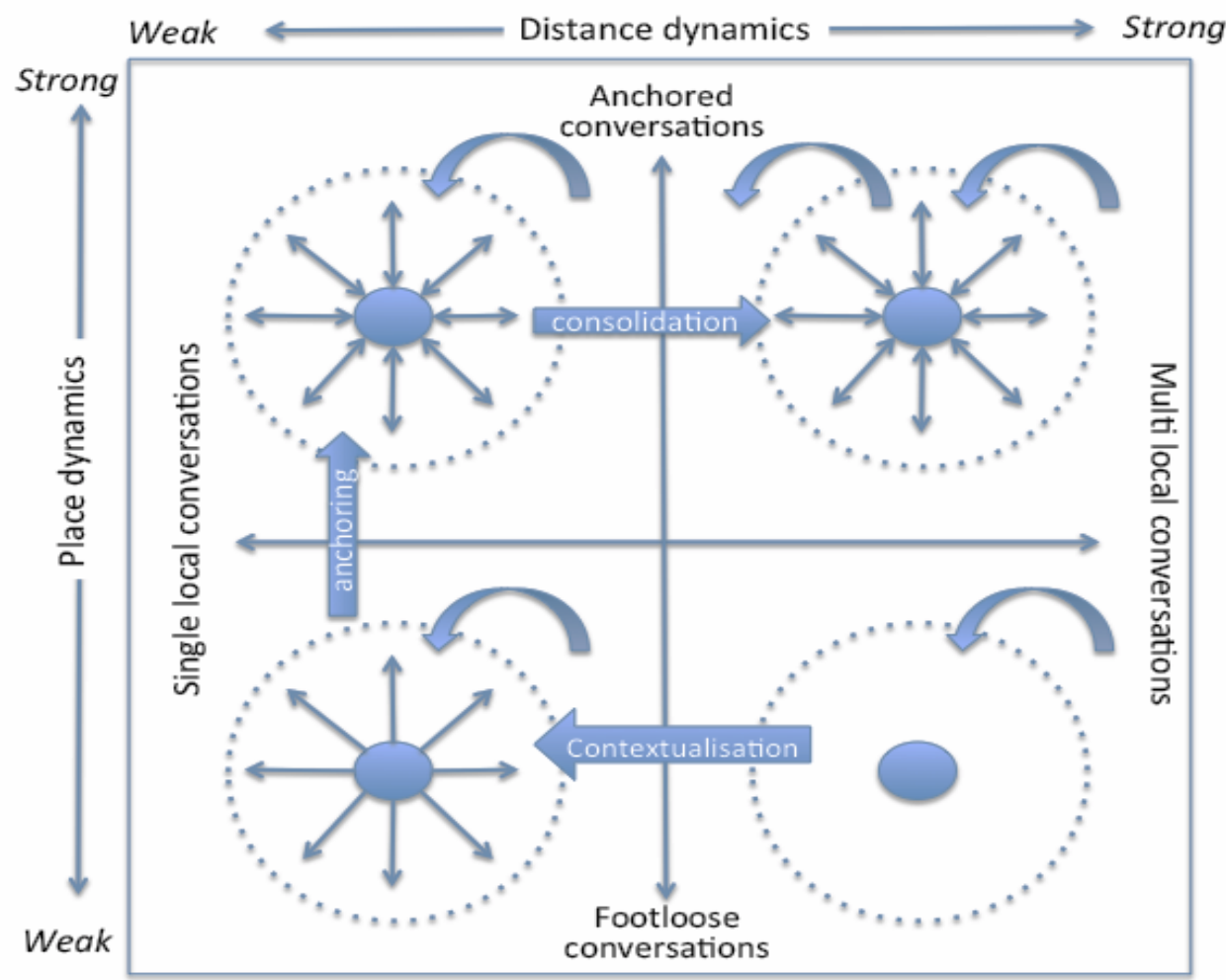

Source: own elaboration based on Rutten (2016) and Crevoisier and Jeannerat (2009)

As can be seen from the figure, the scenarios presented above are not intended as static categories. Specifically, procurement authorities engaged in potentially footloose conversations could aim to contextualise procurement through 
incorporating relevant place based social and environmental considerations. Procurement can be further anchored through building up supply capabilities and more closely engaging with the supply base and connecting it with global capabilities. Further consolidation mechanisms are aimed at moving into multi-local anchored conversations in which the priorities and interests of multiple places, as well as the global character of knowledge are considered. Future research should look for evidence of these potential dynamics.

\section{Discussion and conclusion}

While interest in the use of procurement to spur innovation-driven economic development has been on the rise, little effort seems to have been made thus far to link (typically aspatial) accounts of public procurement of innovation and the regional innovation literature. In the current context of place-based innovation and smart specialisation this seems particularly odd. Public procurement is a multipurpose policy, pursuing multiple economic, social and environmental goals. Adding a further additional goal of promoting innovation, in the form of PPI, may be particularly challenging for local procurers, given their small scale and purchasing power, and consequently often limited implementation capacity. Not surprisingly, then, the PPI literature has tended to focus on national or sectoral policies.

In particular, it seems strange to see so much emphasis on social interaction (such as user-producer interaction) in discussions of PPI whilst the spatial implications of interaction remain underexplored. We have argued that knowledge creation processes involving users and producers have both a social and a spatial dimension. We have adopted the notion of conversations to emphasise the social and spatial embedding of innovation shaping interactions in the context of public procurement. By proposing an analytical framework, the paper aims to generate more nuanced discussions around the questions of when and how can procurement be used as a regional policy tool. We also seek to extend the debate around 'anchor organizations' which, in our view, does not currently pay sufficient attention to knowledge and learning, and connect it to more dynamic approaches in contemporary economic geography literature.

Applying the notion of conversations is useful in that it draws attention to the fluid interpretative stage before and during the formal procurement process where needs are defined and collectively constructed with the market, end users and other stakeholders. In evolutionary terms, conversations are a mechanism supporting both variety generation and selection. Conversations are often 'spatially sticky' in that they take place between actors that are strongly connected to a place and/or that may benefit from its qualities. We have argued that procurement may be anchored to a particular location either by paying attention to the quality of place in shaping and articulating public sector needs or by aligning them to the specific needs of a location. This kind of practice is in stark contrast to efficiency-oriented procurement based around narrow, 'footloose' specifications. 
We have considered what public procurement as a shared conversational space might look like. We have drawn on a number of examples to illustrate how such conversations have contributed to better and more innovative procurement outcomes, for instance by: involving place-based assets (including intellectual assets) in discussions around the definition of issues and problems; making use of local networks to tap into these resources and communicate/raise awareness of medium to long term market opportunities; incorporating a wider range of regional stakeholders in conversations in order to get a broader, richer understanding of place based needs so they can be translated into tender requirements; extending the conversation to similar organizations to share standards and good practice (thus reducing the risk of silo thinking); developing a common vision of requirements that are reflective of the needs of a location (for instance around culture, regeneration or the environment); and sharing experiences and constructing scale by means of consolidating demand in order to gain leverage in the market and scale up local experiments.

Notwithstanding the current high level of interest in how public procurement might spur innovation, in practice there remains a tendency to privilege short-term efficiency considerations. Efficiency leaves little room for experimentation and is therefore often incompatible with innovation (Potts, 2009). On the other hand, evolutionary processes require selection as well as the generation of variation and the stumbling block for a more evolutionary approach to public intervention in the search for innovation-driven economic development has been the challenge of knowing when it is appropriate to promote variety and when, in contrast, it is time to make a selection (or to allow a selection to be made). We would argue that, by anchoring conversations to particular places whilst involving a broader range of actors in conversations as early as possible, it may be possible to square this circle. Conversations can allow actors to come together to share goals and ideas, promoting variety in problem understandings and potential solutions. But in helping actors understand each other's goals and requirements conversations also promote mutual adaptive co-ordination, a process that supports the selection of particular options to take forward (Edelenbos and Teisman, 2008). Proximity and trust may help these conversations. However 'anchoring' procurement might also have tradeoffs, especially where needs are highly 'context specific' or where local institutions lack capabilities and power to involve expert outsiders in these conversations.

All of the above suggests that more empirical attention should be given to understanding the role played by conversations across different geographies in shaping procurement outcomes, positive and negative, and in particular the question as to when it is appropriate to attempt to anchor these conversations to place. It is also important to advance towards a collaborative and multi-scalar use of public procurement and to complement local processes with supra-local ones, in order not only to improve regional government capabilities but also to take advantages of synergies across different levels. We believe that these are important first steps towards building better rationales for the use of public procurement to promote place-based innovation-driven economic development. 


\section{References}

Aho E (2006) Creating an Innovative Europe. Report of the Independent Expert Group on R\&D and Innovation. Available from: http://ec.europa.eu/investin-research/pdf/download_en/aho_report.pdf.

Amin A and Roberts J (2008) Knowing in action: Beyond communities of practice. Research Policy 37(2): 353-369.

Amin A and Thrift N (1995) Institutional issues for the European regions: from markets and plans to socioeconomics and powers of association. Economy and Society 24(1): 41-66.

Aschhoff B and Sofka W (2009) Innovation on demand-Can public procurement drive market success of innovations? Research Policy 38(8): 1235-1247.

Barca F, McCann P and Rodríguez-Pose A (2012) The Case for Regional Development Intervention: Place-Based Versus Place-Neutral Approaches. Journal of Regional Science 52(1): 134-152.

Bathelt H, Malmberg A and Maskell P (2004) Clusters and knowledge: local buzz, global pipelines and the process of knowledge creation. Progress in Human Geography 28(1): 31-56.

Binz C, Truffer B and Coenen L (2014) Why space matters in technological innovation systems-Mapping global knowledge dynamics of membrane bioreactor technology. Research Policy 43(1): 138-155.

Binz C, Truffer B and Coenen L (2016) Path Creation as a Process of Resource Alignment and Anchoring: Industry Formation for On-Site Water Recycling in Beijing. Economic Geography 92(2): 172-200.

Boschma R (2005) Proximity and Innovation: A Critical Assessment. Regional Studies 39(1): 61-74.

Bunnell TG and Coe NM (2001) Spaces and scales of innovation. Progress in Human Geography 25(4): 569-589.

Chicot J and Bleda M (2016) The role of public procurement of innovation in the formation of markets: Knowledge coordination problems and instruments. Paper presented at the International Joseph A. Schumpeter Society, Montreal, 5th July 2016

CLES (2015a) Building a new local economy: Lessons from the United States. Manchester: Centre for Local Economic Strategy.

CLES (2015b) Creating a good local economy. The role of anchor institutions. Manchester: Centre for Local Economic Strategy. 
Coenen L, Benneworth P and Truffer B (2012) Toward a spatial perspective on sustainability transitions. Research Policy, Special Section on Sustainability Transitions 41(6): 968-979.

Crevoisier $\mathrm{O}$ and Jeannerat H (2009) Territorial Knowledge Dynamics: From the Proximity Paradigm to Multi-location Milieus. European Planning Studies 17(8): 1223-1241.

Cueto, L, Garrido, J.M, 2013. Compra pública Innovadora. Fundamentos e Instrumentación. Netbiblio. Madrid, Spain.

Dale-Clough L (2015) Public procurement of innovation and local authority procurement: procurement modes and framework conditions in three European cities. Innovation: The European Journal of Social Science Research 28(3): 220-242.

Edelenbos J and Teisman GR (2008) Public-private partnership: on the edge of project and process management. Insights from Dutch practice: the Sijtwende spatial development project. Environment and Planning C: Government and Policy 26: 614-626.

Edler J and Georghiou L (2007) Public procurement and innovation Resurrecting the demand side. Research Policy 36(7): 949-963.

Edler J and Yeow J (2016) Connecting demand and supply: The role of intermediation in public procurement of innovation. Research Policy 45(2): 414-426.

Edler J, Edquist C, Georghiou L, Hommen, L, Hafner, S, Papadakou, M, Rigby, J, Rolfstam, M, Ruhland, S, Tsipouri, L. (2006) Innovation and Public Procurement: Review of Issues at Stake. Brussels: European Commission.

Edler J, Georghiou L, Uyarra E, Yeow, J (2011) Procurement and Innovation: Underpinning the debate. Background Paper: UNDERPINN project. Manchester: Manchester Institute of Innovation Research.

Edler, J, Rolfstam, M, Tsipouri, L, \& Uyarra, E (2015). Risk management in public procurement of innovation: a conceptualization. In: Edquist C, Vonortas NS, Zabala-Iturriagagoitia JM, et al. (eds), Public Procurement for Innovation, Edward Elgar Publishing.

Edquist C and Zabala-Iturriagagoitia JM (2012) Public Procurement for Innovation as mission-oriented innovation policy. Research Policy 41(10): 1757-1769.

Edquist C, Hommen L and Tsipouri LJ (2000) Public Technology Procurement and Innovation. Kluwer Academic Pub.

Edquist C, Vonortas NS, Zabala-Iturriagagoitia JM, Edler, J. (2015) Public Procurement for Innovation. Cheltenham: Edward Elgar Publishing. 
Ehlenz MM (2015) Neighborhood Revitalization and the Anchor Institution Assessing the Impact of the University of Pennsylvania's West Philadelphia Initiatives on University City. Urban Affairs Review: 1078087415601220.

European Commission (2012) Guide to Research and Innovation Strategies for Smart Specialisation (RIS 3). Brussels: European Commission.

Ferreira da Cruz N, Simoes P and Marques RC (2013) The hurdles of local governments with PPP contracts in the waste sector. Environment and Planning C: Government and Policy 31: 292-307.

Gee S and Uyarra E (2013) A role for public procurement in system innovation: the transformation of the Greater Manchester (UK) waste system. Technology Analysis \& Strategic Management 25(10): 1175-1188.

Georghiou L, Li Y, Uyarra E, Edler, J. (2010) Public Procurement for Innovation in Small European Countries. Manchester / Brussels. Available from: http://www.eraprism.eu/documents/4.4\%20and\%204.5\%20del\%20pu blic\%20procurement.pdf.

Georghiou L, Edler J, Uyarra E, Yeow, J. (2014) Policy instruments for public procurement of innovation: Choice, design and assessment. Technological Forecasting and Social Change 86: 1-12.

Geroski PA (1990) Procurement policy as a tool of industrial policy. International Review of Applied Economics 4(2): 182-198.

Healy A and Morgan K (2012) Spaces of Innovation: Learning, Proximity and the Ecological Turn. Regional Studies 46(8): 1041-1053.

Hildreth P and Bailey D (2014) Place-based economic development strategy in England: Filling the missing space. Local Economy 29(4-5): 363-377.

Hodson M and Marvin S (2010) Can cities shape socio-technical transitions and how would we know if they were? Research Policy 39(4): 477-485.

Hommen L and Rolfstam M (2009) Public procurement and innovation: Towards a taxonomy. Journal of Public Procurement 9(1): 17-56.

Howlett M and Rayner J (2007) Design principles for policy mixes: cohesion and coherence in 'new governance arrangements'. Policy and Society 26(4): 118.

ICIC (2011) Anchor Institutions nad Urban Economic Development: From Community benefith to shared value. Inner City Insights 1(2).

Knutsson H and Thomasson A (2014) Innovation in the Public Procurement Process: A study of the creation of innovation-friendly public procurement. Public Management Review 16(2): 242-255. 
Lagendijk A (2002) Beyond the regional lifeworld against the global systemworld: towards a relational -scalar perspective on spatialeconomic development. Geografiska Annaler: Series B, Human Geography 84(2): 77-92.

Laranja M, Uyarra E and Flanagan K (2008) Policies for science, technology and innovation: Translating rationales into regional policies in a multi-level setting. Research Policy 37(5): 823-835.

Lember V, Kalvet T and Kattel R (2008) Urban competitiveness and public procurement for innovation. Institute of Humanities and Social Sciences TU (ed.).

Lember V, Kalvet T and Kattel R (2011) Urban Competitiveness and Public Procurement for Innovation. Urban Studies 48(7): 1373-1395.

Lember V, Kalvet T and Kattel R (2013) Public procurement policy for innovation: International perspectives. Springer.

Lember V, Kattel R and Kalvet T (2015) Quo vadis public procurement of innovation? Innovation: The European Journal of Social Science Research 28(3): 403-421.

Lester RK and Piore MJ (2004) Innovation-The Missing Dimension. Harvard University Press.

Liedtka JM and Rosenblum JW (1996) Shaping Conversations: Making Strategy, Managing Change. California Management Review 39(1): 141-157.

Lowe N and Feldman M (2008) Constructing entrepreneurial advantage: consensus building, technological uncertainty and emerging industries. Cambridge J Regions Econ Soc 1(2): 265-284.

Lowe N and Feldman M (2015) Breaking the Waves: Innovation at the Intersections of Economic Development Policy. Working paper, Chapel Hill: University of North Carolina.

Malecki PEJ (2014) The Geography of Innovation. In: Fischer MM and Nijkamp P (eds), Handbook of Regional Science, Springer Berlin Heidelberg, pp. 375389.

Morgan K (2008) Greening the Realm: Sustainable Food Chains and the Public Plate. Regional Studies 42(9): 1237-1250.

Morgan K (2013) Path Dependence and the State: The Politics of Novelty in Old Industrial Regions. In: Cooke P (ed.), Re-framing Regional Development: Evolution, Innovation and Transition, Routledge, pp. 318-340.

Morgan K and Henderson D (2002) Regions as Laboratories: the Rise of Regional Experimentalism in Europe. In: Gertler MS and Wolfe DA (eds), Innovation 
and Social Learning, International Political Economy Series, Palgrave Macmillan UK, pp. 204-226.

Morgan K and Sonnino R (2007) Empowering consumers: the creative procurement of school meals in Italy and the UK. International Journal of Consumer Studies 31(1): 19-25.

Morgan K and Sonnino R (2013) The School Food Revolution: Public Food and the Challenge of Sustainable Development. Routledge.

Moulaert F and Sekia F (2003) Territorial Innovation Models: A Critical Survey. Regional Studies 37(3): 289-302.

OECD (2015) Government at a Glance 2015. OECD Publishing.

OGC (2004) Capturing Innovation: Nurturing. Suppliers' Ideas in the Public Sector. London: Office of Government Commerce.

OGC (2006) Aggregation: Is bigger always better?. London: Office of Government Commerce.

Oinas P and Malecki EJ (2002) The Evolution of Technologies in Time and Space: From National and Regional to Spatial Innovation Systems. International Regional Science Review 25(1): 102-131.

Mccann, P, Ortega-Argilés, R, (2015) Smart Specialization, Regional Growth and Applications to European Union Cohesion Policy. Regional Studies 49 (8), 1291-1302.

Peck F and Cabras I (2008) Public Procurement and Regional Development-the impact of local authority expenditure on local economies. Available from: http://www.regional-studies-assoc.ac.uk/events/2008/mayprague/papers/Peck.pdf.

Peck F, Connolly S, Durnin J, Jackson, K.(2013) Prospects for 'place-based' industrial policy in England The role of Local Enterprise Partnerships. Local Economy 28(7-8): 828-841.

Pelkonen A and Valovirta V (2015) Can service innovations be procured? An analysis of impacts and challenges in the procurement of innovation in social services. Innovation: The European Journal of Social Science Research 28(3): 384-402.

Phillips W, Knight L, Caldwell N, Warrington, J. (2007) Policy through procurement-The introduction of digital signal process (DSP) hearing aids into the English NHS. Health Policy 80(1): 77-85.

Pickernell D, Kay A, Packham G, Miller, C. (2011) Competing Agendas in Public Procurement: An Empirical Analysis of Opportunities and Limits in the UK for SMEs. Environment and Planning C: Government and Policy 29(4): 641658. 
Potts J (2009) The innovation deficit in public services: The curious problem of too much efficiency and not enough waste and failure. Innovation 11(1): 34-43.

Roberts DJ and Siemiatycki M (2015) Fostering meaningful partnerships in public-private partnerships: innovations in partnership design and process management to create value. Environment and Planning C: Government and Policy 33: 780-793.

Rolfstam M (2013) Public Procurement and Innovation. Cheltenham: Edward Elgar Publishing.

Rolfstam M (2015) Public procurement of innovation for a better world: a consolidation or a new beginning? Innovation: The European Journal of Social Science Research 28(3): 211-219.

Rothwell R (1984) Creating a Regional Innovation-Oriented Infrastructure: The Role of Public Procurement. Annals of Public and Cooperative Economics 55(2): 159-172.

Rutten R (2016) Beyond proximities The socio-spatial dynamics of knowledge creation. Progress in Human Geography, published online before print.

Stark D (2011) The Sense of Dissonance: Accounts of Worth in Economic Life. Princeton University Press.

Timmermans B and Zabala-Iturriagagoitia JM (2013) Coordinated unbundling: A way to stimulate entrepreneurship through public procurement for innovation. Science and Public Policy 40(5): 674-685.

Uyarra E (2010) Opportunities for innovation through Local Government Procurement: A Case Study of Greater Manchester. Research Report, London: NESTA.

Uyarra E and Flanagan K (2010) Understanding the Innovation Impacts of Public Procurement. European Planning Studies 18(1): 123-143.

Uyarra E and Gee S (2013) Transforming urban waste into sustainable material and energy usage: the case of Greater Manchester (UK). Journal of Cleaner Production, Special Issue: Advancing sustainable urban transformation 50: 101-110.

Uyarra E, Edler J, Garcia-Estevez J, Georghiou, L, Yeow, J (2014) Barriers to innovation through public procurement: A supplier perspective. Technovation 34(10): 631-645.

Wenger E (1998) Communities of Practice: Learning, Meaning, and Identity. Cambridge: Cambridge University Press. 
Wesseling JH and Edquist C (2016) Public procurement for innovation: lessons from the procurement of a navigable storm surge barrier. Papers in Innovation Studies, Lund University.

Whyles G, van Meerveld H and Nauta J (2015) Forward Commitment Procurement: a practical methodology that helps to manage risk in procuring innovative goods and services. Innovation: The European Journal of Social Science Research 28(3): 293-311.

Yeow J, Uyarra E and Gee S (2015) 'Closing the loop - Examining the case of the procurement of a sustainable innovation'. In: Edquist C, Vonortas NS, Zabala-Iturriagagoitia JM, et al. (eds), Public Procurement for Innovation, Edward Elgar Publishing.

Zabala-Iturriagagoitia JM (2013) The Malmö 'city of the future' urban planning project. Report for 'Generating Knowledge Products to Support the Implementation and Dissemination of LED Policies throughout Latin America and the Caribbean (LAC)' project. FOMIN-BID. Washington.

Zelenbabic D (2015) Fostering innovation through innovation friendly procurement practices: a case study of Danish local government procurement. Innovation: The European Journal of Social Science Research 28(3): 261-281. 